\title{
The Strenght of Socio-Affective Strategy With Skype Video Call in the
}

\section{Teaching Speaking}

\author{
By: \\ Varia Virdania Virdaus \\ varia.virdaus@narotama.ac.id
}

\begin{abstract}
To speak English for most Indonesian students is not an easy matter. Many of them feel shy and lack of confidence. That is why the teachers should use an appropriate strategy to help them improve their speaking ability. This study was a quasi- experiment applying non- randomized control group pre-test posttest design and the subjects of which were the students of Management Class of STIE Perbanas Surabaya. The researcher took two classes of the first semester. They were Class O.2 having 25 students as a control group, and class B.1 having 26 students as an Experimental group. The study has proved that socio affective strategy with Skype is more effective than conventional strategy when used in the teaching speaking and the students who were taught using socio affective strategy with Skype could be more interested to communicate with English language.
\end{abstract}

Keywords: efectiveness, socio affective strategy, SKYPE, teaching speaking,

\begin{abstract}
Abstrak: Berbahasa Inggris bagi sebagian besar siswa Indonesia bukanlah perkara mudah. Banyak dari mereka merasa malu dan kurang percaya diri. Itulah sebabnya para guru harus menggunakan strategi yang tepat untuk membantu mereka meningkatkan kemampuan berbicara mereka. Penelitian ini adalah eksperimen semu yang menerapkan desain post-test post-test kelompok kontrol non-acak dan subjek penelitian adalah siswa Kelas Manajemen STIE Perbanas Surabaya. Peneliti mengambil dua kelas pada semester pertama. Mereka adalah Kelas O.2 yang memiliki 25 siswa sebagai kelompok kontrol, dan kelas B.1 memiliki 26 siswa sebagai kelompok eksperimen. Penelitian ini telah membuktikan bahwa strategi sosial-efektif dengan Skype lebih efektif daripada strategi konvensional ketika digunakan dalam pengajaran berbicara dan siswa yang diajar menggunakan strategi sosial-efektif dengan Skype dapat lebih tertarik untuk berkomunikasi dengan bahasa Inggris..
\end{abstract}

Kata Kunci: keefektifan, strategi sosial afektif, SKYPE, pengajaran berbicara

\section{INTRODUCTION}

Speaking is one of difficult skills to practice. It is not only caused the weak of them in grammar and vocabulary but also it needs much time for them to master it. Rifai (2012) has pointed out that in speaking, they are still confused how to arrange a right sentence and to choose the correct words. Florez (1999) states that speaking is an interactive process of constructing meaning that involves producing 
and receiving and processing information. It shows that speaking is a productive skill; it is a process of producing and expressing thoughts, ideas, or opinion to be involved in communication. For speaking skill is a productive skill, language learners should be able to express the language orally. Such as stated by Riggenback and Lazaraton (1991, cited in Widiati\&Cahyono, 2006: 269), language learners are considered successful if they can communicate effectively in the language. It means that the parameter of learning success depends on the fluency of language that is produced.

In mastering speaking skill, language learners should apply English language in their daily life. Learners often feel confused how to begin practicing it. They need an appropriate strategy to maximize in the mastering English. Besides, an appropriate language learning strategy can improve the proficiency and self-confidence (Oxford, 1990:1). Learners can use socio-affective strategy to overcome speaking skills problem. Habte-Gabr (2006) has defined that socioaffective strategies are those which are nonacademic in nature and involve stimulating learning through establishing a level of empathy between the instructor and student. Socio-affective strategy includes two factors such as emotions and attitudes (Zeynali, 2015). It means that socio-affective strategy is a strategy to face speaking skill by stimulating the learners out of academic process. It is used by combining social and affective values. By this strategy learners can share their daily activities with its emotions or attitudes correctly and smoothly with English language.

A unique fact in a foreign language school is that the students lack of time to deepen the target language-English. Language learners also need to practice their speaking skill with native speakers to improve their skill. Many researchers also take these issues to be concerned. The use of Information and Communication Technology (ICT) has been a strong necessity to be effectively used in the learning process (Santosa, 2008). Researcher uses skype video call application to ward off the limitation time in a classroom. Skype is a software application that uses voice over internet protocol (VoIP) technology "which converts voice signals into data streams sent over the internet and converted back 
to audio by the recipient's computer" (Educause, 2007:2). Skype, a software application for online communication, has been used in classes at various levels, providing many possibilities for teaching and learning (Blankenship, 2011; Foote, 2008; Messner, 2009, 2010). Then, teaching English via Skype allows English teachers and students from many countries connect in new ways. By this media students can communicate using English language orally to the foreign people. Besides that the usage of this application is easy to be applied. It opens up so many opportunities for English teachers who want to broaden their students speaking skill while taking control of their work schedule. Teacher only needs to support, motivate, and guide the students in applying their English skill by this media.

In line with the above statements, the research problem is formulated as follows: Can socio-affective strategy with skype video call application give better achievement than conventional strategy in the teaching speaking.

\section{THEORITICAL BASES}

\section{Definition of Speaking}

There are various ideas given by language experts in defining speaking. Although they have difference in the ideas, the differences are still quite acceptable and logic for each of them gives a strong reason towards speaking skill. Speaking is one of productive skill in the learning language and it is often known as a communicative competence. According to Hymes (cited by Brown:2000), "communicative competence is an aspect of our competence that enables us to convey and interpret messages and to negotiate meanings interpersonally within specific contexts.” While Savignon (cited by Brown:2000) defines; "communicative competence is relative, not absolute, and depends on the cooperation of all the participants involved." Harmer (1991) has stated that speaking skill is not only about knowledge of language features, but also the ability on how to process information and language on the spot. It is clear that speaking skill is one of the main parts of language usage. The important of 
speaking ability is as the product of language learning which is applied in the daily activities.

\section{Teaching Speaking}

Language teacher should understand well four main skills in the teaching language. Those main language skills are listening, speaking, reading, and writing. To master it, each skill needs its own techniques, and strategies According to Brown (2000), teaching speaking is teaching productive skill of oral communication and it is used the interaction between two modes of performances (speaking and listening). He also declared about the kinds of teaching speaking and types of speaking in the classroom.

\section{a. Kinds of Speaking Course}

1) Conversational Discourse

Richards (cited by Brown, 2000:267) said, "The conversation class is something of an enigma in language teaching”. The goals and techniques for this course are extremely diverse, depending on the student, teacher, and all the context of this class (Brown, 2000:267).

2) Teaching Pronunciation

This course is a controversy course because it is focuses on the tiny phonological details of language, and English has two different accents (British and American).

3) Accuracy and Fluency

Accuracy contains clear, articulate, grammatically, and phonologically correct; while fluency is flowing natural. These courses are clearly important in the communicative language teaching`s goal, where fluency is the first goal, then accuracy allows the students to focus on the elements of phonology, grammar, and discourse in their spoken output.

4) Affective Factors 
This course is about how to reduce anxiety in the applying speaking skill. Brown (2000) mentioned that teacher should provide the kind of warm, embracing climate that encourages students to speak.

5) The Interaction Effect

The matters of applying speaking for language learners are what to say things, to be sure how to say something, and when to say. One learner`s performance depends on the other person who is talking with. In other hand, interaction effect is a course which provides a meeting for having interaction among of the students. So, this interaction effect course will make the students to be braver for applying their speaking skill.

\section{b. Types of Speaking Classroom Performance}

These are six types of speaking performances that students are expected to carry out in the classroom:

1) Imitative

The teacher plays a tape recorder or the other media then the students repeat the voices.

2) Intensive

Students repeat some voices and practice some phonological or grammatical aspect.

3) Responsive

Responsive means students give short replies to teacher or students initiated questions or comments.

4) Transactional (dialogue)

Transactional language carried out the purpose of conveying or exchanging information (contains such as a negotiation)

5) Interpersonal (dialogue)

Interpersonal dialogue carried out more purpose of maintaining social relationship than transmission of fact and information.

6) Extensive (monologue) 
Extensive monologue is an advanced level. The students extend monologues in the form of oral reports, summaries, and short speeches. It is more formal and deliberative.

\section{Socio-affective strategy}

Learning strategies consists three main categories: metacognitive, cognitive, and socio affective (O`Malley\&Chamot, 1994). Brown (2000) stated that socio-affective strategy deals with learners 'interaction with the others. According to Zeynali (2015) socio affective strategy is learning by interacting with others, such as grouping with other learners and asking to the teacher`s help.

Socio/affective strategy can be known that they are related with socialmediating activity and transacting with others. It uses cooperation and question for clarification (Zeynali:2015).

In other hand, affective strategy identifies one`s mood and anxiety level, feelings, rewarding oneself who has good performance, and have positive self-talk (Magno, 2010). Zeynali (2015) also mentioned the examples of this strategy, such as asking questions to get verification, asking for clarification of a confusing point, asking for help in doing a language task, talking with a native-speaking conversation partner, and exploring cultural or social norms.

Social strategies deal with the people and environment surrounding the learners. It leads the students to increase interaction with the target language. It is an activity which give the students opportunities to be exposed to and practice their knowledge (Hismanoglu, 2002).

While Habte-Gabr (2006) has defined that socio-affective strategies are nonacademic in nature and involve stimulating learning through establishing a level of empathy between the instructor and student. Socio-affective strategy includes considering factors such as emotions and attitudes (Oxford R.L cited by Zeynali: 2015).

Scimonelli (2002) argued that affective and social language learning strategies as well as communication strategies are the areas in which the teacher's intervention should come first, to develop positive environment of mind for 
students and help them to overcome the stress and sense of discomfort that a poor or low oral command of English.

Chou (2004) contended that specifically for the use of socio affective strategy because these strategies can help EFL learners regulate their emotion and attitudes towards learning and learn to interact with others successfully. The benefits of socio-affective strategy based on Jose`s research (2010):

a. It helps the teacher to create a comfortable classroom atmosphere.

b. It helps the learners better understand and experience the social and affective side of their learning process.

c. It constructs students` beliefs, attitudes, and motivations.

d. It helps students to focus much more on memorizing vocabulary, understanding the language, and compensating for knowledge gaps than paying attention to the affective, social, and decision-making aspects of language learning.

\section{SKYPE Application}

Skype is a software application that uses voice over Internet protocol (VoIP) technology "which converts voice signals into data streams that are sent over the Internet and converted back to audio by the recipient's computer" (Educause, 2007, p.2).

Skype, a software application for online communication, has been used in classes at various levels, providing many possibilities for teaching and learning (Blankenship, 2011; Foote, 2008; Messner, 2009, 2010).

According to Sivakumar(2015), skype in the classroom strives to enrich students` learning experiences to discover new cultures, languages and ideas.

Skype is only a tool for e-learning. So it will have neither some advantages nor the disadvantages. These are the advantages of Skype in the teaching-learning process based on

a. This application helps the students to improve their linguistics skills via speaking to native speakers of the target language. 
b. Teacher can use video conferencing to hold teaching sessions with their students while being away from the classroom.

c. Teacher can connect the class with other class in the world.

d. Teacher can use skype to collaborate with each other. They can, for instance, do peer tutoring by havingan experienced teacher or mentor watch one teaching via skype and then give the feedback.

e. Teacher can have guest speakers' talk directly with the students.

f.It can be used for students to practice speaking class while the limitation time is going on.

This part will explain the disadvantages of using skype for learning process

a. Skype requires the computer to be turned on all the time.

b. It needs a good signal to use.

c. It only can be used for $3 \mathrm{G}$ hand phone and the cordless RTX Dual phone.

\section{Some Related Studies}

First, Jose (2010) showed in his research that Affective factors are important considerations that both teachers and students need to reflect on to gain a deeper understanding of the nature of language learning and, ultimately, to gain insight about themselves.

Second, according to Arini (2013) there are three important results from her study. First, there are three sets of affective learning strategies that can be used in the teaching and learning process of speaking such as anxiety-reducing strategies, encouraging-oneself strategies, and monitoring-emotion strategies. Second, the use of affective learning strategies in the teaching and learning process of speaking improves the students "confidence, motivation, involvement, and aspects of speaking skills. Based on the qualitative data analyses, the students can speak at the normal speech without pausing, respond to the expressions appropriately, speak without being shy, speak with correct pronunciation, use language functions with correct grammar, and join the teaching and learning process enthusiastically. Meanwhile, the quantitative data analyses show the improvements of the mean scores of the aspects of speaking skills. They are 1.12 
for fluency, 0.46 for accuracy, 0.85 for pronunciation, and 1.18 for vocabulary. There is also an increase of the average score of students ${ }^{\text {ee }}$ speaking skills of 0.9437 from 6.1826 (pre-test) to 7.1263 (post test). According to the $t$ statistic, the difference is significant at $p<0.05$. Third, there are two kinds of students ${ }^{\text {ee }}$ responses toward the use of affective learning strategies. They are the studentse willingness to use the strategies and the students ${ }^{\text {ee }}$ difficulties in using the strategies.

Third, Syafri`s (2016) mentioned in her research that socio-affective strategy needs other adding strategy to make the research completed. She used cultural strategy to appropriate teaching speaking strategy. When she used sociocultural-affective strategy, the research showed that these strategies can improve students speaking ability.

Last, Hashemi and Azizinezhad (2011) concluded their research about Skype for language learning as fellow: Students have more chances to use English for real communication and their motivation to study becomes stronger. They speak more English even though their teachers do not force them because web conferencing is enjoyable to them. Teachers can also learn a lot from authentic communications with native speakers of English. Second language learners and educators can talk to people all over the world even though they are sitting in their usual classroom. Web conference lessons increase student motivation to study English significantly.

\section{METHOD}

This study applies the quantitative approach because it ideals with certain numbers of variables and numerical data. The data used in this study are interval data in the form of students' scores of English speaking test. The research method of this study is quasi- experimental applying non- randomized control group pretest and post-test control design. The non-randomized control group, pre-test and post-test design is a good second choice when random assignment of subject group is not possible (Ary; 2010). There are some reasons for taking this design: 
a) The research was conducted without changing the setting of the class, the observed classes were not changed in their characteristics and setting; b) The researcher only collaborated with the teacher for doing this study to create the natural condition of the class, to avoid the students feel being observed which could cause the extraneous variable; c) The two classes were used in this research had been separated long before the researcher conducted the research by considering the sampling technique; d) The research was executed using the time schedule of the teaching arranged by the school as before.

The subjects of this study were the students of Management Class of STIE Perbanas Surabaya. The researcher took two classes of the first semester. They were Class O.2 having 25 students as a control group, and class B.1 having 26 students as an Experimental group.

From this research, the researcher wants to find out the effect of two teaching strategy, they are socio-affective strategy with SKYPE media and cognitif strategy without media in the teaching and learning process. This quantitative experimental research consists of three steps. The first step is pre-test, the second step is the treatment and the last is post-test. This research needs two groups to apply, one group as an experimental group and the other one is the control group. The researcher acted as the teacher in giving treatment of socioaffective strategy used SKYPE. The experimental group would receive the treatment while the control group would not. To make it clear see the following table:

Table: Non-randomized control group pretest-posttest design

\begin{tabular}{|l|c|c|c|}
\hline \multicolumn{1}{|c|}{ Group } & Pre-test & Treatment & Post-test \\
\hline Experimental Group & Y1 & $\mathrm{X}$ & Y2 \\
\hline Control Group & Y1 & - & Y2 \\
\hline
\end{tabular}

Y1 : Observation in Pretest (Test was given before treatment)

Y2 : Observation in Posttest (Test was given after treatment) 
$X$ : Treatment using socio-affective strategy with skype in the teaching speaking about water cycle.

Ary (2010) stated that a variable is a construct or a characteristic that can take on different values or scores. There are seven kinds of variables. They are dependent, independent, intervene, moderator, confounding, control, and concomitant variable. However, related to hypothesis of this study there are only two variables observed. They are dependent and independent variable. The independent variables were conventional learning (cognitive strategy) and socio affective strategy with SKYPE to teach speaking skill based on an explanation text, while the dependent variable was the students' achievement presented by their scores at the end of the treatment by using those two teaching methods.

Since non-randomized pretest-posttest control group design was used in this research, the researcher applied ANCOVA formula to prove the hypothesis as suggested by Pallant (2000, chapter 20: 1), stating that ANCOVA can be used when you have two group pretest/posttest design (e.g., comparing the impact of two different intervention, taking before and after measure of the groups), he also states that the pretest scores are treated as a covariate to control for pre-existing differences between groups. Moreover, as these groups may differ on a number of different attributes, ANCOVA can be used in an attempt to reduce some of these differences (Stevens, 1996 in Pallant 2000). In order to gain accurate and correct data, the researcher has calculated the data by using SPSS for window version 20 .

\section{FINDING}

1. One way Analysis of Covariate Dependent Variable: POSTTEST

\begin{tabular}{|l|r|r|r|r|r|}
\hline Source & $\begin{array}{r}\text { Type III Sum of } \\
\text { Squares }\end{array}$ & \multicolumn{1}{c|}{ df } & Mean Square & \multicolumn{1}{c|}{ F } & \multicolumn{1}{l|}{ Sig. } \\
\hline Corrected Model & $906.171^{\mathrm{a}}$ & 2 & 453.085 & 42.795 & .000 \\
Intercept & 176.571 & 1 & 176.571 & 16.678 & .000 \\
STRATEGY & $\mathbf{4 4 . 3 8 4}$ & $\mathbf{1}$ & $\mathbf{4 4 . 3 8 4}$ & $\mathbf{4 . 1 9 2}$ & $\mathbf{. 0 4 8}$ \\
\hline
\end{tabular}




\begin{tabular}{|c|c|c|c|c|c|}
\hline PRETEST & 41.271 & 1 & 41.271 & 3.898 & .056 \\
\hline Error & 391.729 & 37 & 10.587 & & \\
\hline Total & 264062.000 & 40 & & & \\
\hline Corrected Total & 1297.900 & 39 & & & \\
\hline
\end{tabular}

a. R Squared = ,698 (Adjusted R Squared $=, 682$ )

Pallant (2000) states if the significant value is less than 0.05 , then the groups (socio affective strategy with skype and cognitive strategy) differ significantly. Based on the above table (labeled Strategy on the SPSS output), the result of the analysis indicates that the null hypothesis saying that both methods (socio affective strategy with skype and cognitive strategy) are equal should be rejected, $\mathrm{F}_{(1,37)}=4.192, \mathrm{P} 0.048<0.05$

Table: Estimated Marginal Means

\begin{tabular}{|l|r|r|r|r|}
\hline STRATEGY & \multicolumn{1}{|c|}{ Mean } & Std. Error & \multicolumn{2}{|c|}{$95 \%$ Confidence Interval } \\
\cline { 4 - 5 } & & & \multicolumn{1}{c|}{ Lower Bound } & Upper Bound \\
\hline SOCIOAFFECTIVE & $83.532^{\mathrm{a}}$ & 1.317 & 80.864 & 86.201 \\
COGNITIVE & $78.568^{\mathrm{a}}$ & 1.317 & 75.899 & 81.236 \\
\hline
\end{tabular}

a. Covariates appearing in the model are evaluated at the following values: PRETEST $=60.90$.

Based on the Estimated Marginal Means, the alternative hypothesis saying that the students who were taught using socio affective strategy with skype achieved better speaking skill than those who were taught using cognitive strategy is accepted, because the mean score for socio affective strategy with skype is $83.532^{\mathrm{a}}$, which is greater than $78.568^{\mathrm{a}}$ for cognitive strategy.

\section{CONCLUSION}

On the basis of results and findings of this study, following conclusions were drawn:

1) The study has proved that socio affective strategy with Skype is more effective than conventional strategy in the teaching speaking. 
2) The students who were taught using socio affective strategy could be more interested to communicate with English language.

\section{RECOMENDATION}

In the light of findings and conclusions of this study, following recommendations were made.

1) The retention aspect of socio affective strategy with Skype may be further researched by taking different time periods and situations where the students are in knowledge of the date of retention test.

2) Previous studies conducted on socio affective strategy in different cultures by different researchers as well as this study prove socio affective strategy as more effective mode of instruction for English as compared to conventional method of teaching. Therefore, teachers of English should use socio affective strategy to improve the academic achievements of students, especially speaking.

3) The results of few studies are insufficient to decide about the maximum use of socio affective strategy in our culture. Thus a series of action researches using different socio affective strategy strategies in different situations i.e. rural, urban, male, female students and mixed genders at different levels are proposed to be carried out.

\section{REFERENCES}

Anna\&michael. (1987). The Cognitive Academic Language Learning Approach: A Bridge to the Mainstream. E-journal. Newbury House Publisher. New York. Retrieved from https://www.TESOL.com

Arini, Windi. (2013). Improving Students Speaking Skills at SMA Muhammadiyah 3 Depok Thtough the Use of affective Learning Strategies in the Academic Year of 2011/2012. Published Thesis. Retrieved from www.eprints.uny.ac.id

Ary, Donald e.I. (2010). Intoduction to Research in Education $8^{\text {th }}$ Edition. Canada Blankenship, M. (2011). How Social Media can and should Impact Higher Education. The Education Digest. 76(7), 39-42.

Brown, H. D. (1999). M\&Ms for language classrooms: another look at motivation. Geogetown University Press. Retrieved from www.Wikitionary.org on March 15th 2018. 
Brown, H. D. (2000). Teaching by Principles. California. Longman press. Cambridge Dictionary Online: https://dictionary.cambridge.org/dictionary/english/boarding-school

Chamot,A.U.\&O`Malley, J.M. (1994). The CALLA Handbook: Implementing the Cognitive Academic Language Learning Approach. White Plains, NY: Addison Wesley Longman.

Chou, Y. (2004). Promoting Learners' Speaking Ability by SocioAffective Strategies. The Internet TESL Journal, 10(9). Retrieved from http://iteslj.org/Articles/Chou-Socioaffective.html

Educause. (December, 2007). 7 Things You Should Know about Skype. Educause Learning Initiative, 1-2. Retrieved on March 14, 2018, from http://net.educause.edu/ir/library/pdf/eli7032.pdf

Florez, C, M. (1999). "Improving Adult English Language Learners' Speaking Skill” [online] Available http://www.ericdigests.org/2000-3/adult.htm (Accesed: 16 March 2018)

Habte-Gabr, e. (2006). The Importance of Socio-Affective Strategies in Using EFL for Teaching Mainstream Subject. The Journal of Humanizing Language Teaching. 8(5). Retrieved 15 March 2018

Harmer, Jeremy. (1991). The Practice of English Language Teaching. Longman Express.

Harris, David P. (1969). Testing English as a Second language. New York: McGraw_Hill Book Company.

Hashemi\&Azizinezad. (2011). The Capabilities of Oovoo and Skype for Language Education. Online Journal. Retrieved on https://www.sciencedirect.com/science/article/pii/s1877042811024499.

Heaton, J.B. (1975). Writing English Language Test. Burnt Mill: Longman Group Limited.

Herlina. (2016). The Effectiveness of Role Play Technique Using Video in Teaching Speaking Skill for Junior High School. Unpublished Thesis. STKIP PGRI Blitar.

Hismanoglu. (2002). Language Learning Strategies in Foreign Language Learning and Teaching. Internet TESL journal. Retrieved at itesl.org/Articles/hismanoglu-Srategies.htm

Hornby.(1974).The new Grolier Webster Internatioanal Dictionary of Current English. New York, Oxford University Press.

Jose, Y. (2010). The Explicit Teaching of Socio-Affective Language Learning Strategies to Beginner EFL Students. The Internet TESL Journal. Retrieved from http://onlinelibrary.wiley.com/doi/10.2307/3586278/full.

Kemendikbud. (2017). Bahasa Inggris K-13 Edisi Revisi 2017. E-book. Retrieved from www.bukupaket.com

Magno, C. (2010). Korean Students 'Language Learning Strategies and Years of Studying English as Predictor of Proficiency in English. TESOL Journal. Retrieved at www.researchgate.net

Ni'ma, Khoirun. (2016). The Effect of TPS Method Using Movie in Teaching Reading Narrative for Junior High School. Unpublished Thesis. STKIP PGRI Blitar. 
Oxford, R. L. (1990). Language Learning Strategies: What Every Teacher Should Know. Boston: Heinle\&Heinle

Pallants, Julie F. (2000). SPSS Survival Manual: A Step by Step Guide to Data Analysis Using SPSS. Faculty of Education Monash University.

Rifai, Saiful (2012). Grammatical Error on Writing. Retrieved from https://scholar.google.com/citations?user=Ri71oBIAAAAJ\&hl=en\#d=gs_m d_cita-

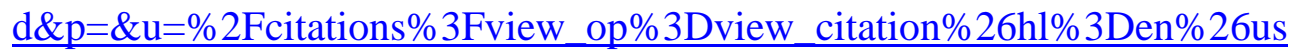
er\%3DRi71oBIAAAAJ\%26citation_for_view\%3DRi71oBIAAAAJ\%3AIjC SPb-OGe4C\%26tzom\%3D-420

Ross, J. (2005). A Long - Term Research Agenda for the Test of Written English. Center for applied linguistics. Washington, D.C.

Stevens. (1996). Applied Multivariate Statistics for the Social Science. New Jersey

Sudijino. (2003). Evaluasi Pendidikan. Jakarta: PT Raja Grafindo Persada.

Scimonelli, P.B. (2002). Language Learning Strategies: Helping the Students Find "IL Metodo". In Norwich Institute for Language Education: Main Assignment. Retrieved from http://web.tiscalinet.it/colabianchi/NorwichSITE/BRUNA\%20main\%20assi gn.-\%20LLS.doc

Sivakumar, R. (2015). Integrating Skype into Education. Online Journal. Retrieved on https://www.researchgate.net/publication/281591535

syafri, Hayati. (2016). Expanding Instructional Model of Socio Affective Strategy for Speaking Skill in Islamic Institution. E-journal. Retrieved from www.ejournal.unp.ac.id

Webster, M. (2000). Collegiate Dictionary. Newyork: Britannica Company

Widiati-Cahyono. (2006). The Teaching of EFL Speaking in The Indonesian Context: The State of The Art". (online) available at https://www.researchgate.net

Zeynali-Simin-Fariborz. 2015. The Effects of Socio-Affective Strategy in The Enhancement of Reading Comprehension among Iranian EFL Learners. (Online). Retrieved from http://www.sciencepublishinggroup.com/j/ijll 